\title{
Digital Video as a Promotional Media and Brand Equity of a Product That has an Influence on Consumer Buying Interest (A Research of Social Media Active Users)
}

\author{
Ayuningtyas Yuli Hapsari * \\ Universitas Widyatama, Jl. Cikutra 204A, 40298, Bandung, Indonesia
}

\begin{abstract}
Objective - The research aims to test influence of promotion in social media and effect of brand equity on Consumer Buying Interest.

Methodology/Technique - This research uses descriptive verification method that examines many as 115 respondents with 15-40 years of age category, because it is an age of active users of social media such as: Instagram, YouTube, Facebook, etc. This study also uses primary data is based on interviews during the pre-survey and distribute questionnaires. After that at the time of processing the data, this study using multiple regression analysis as a verification method to measure how much digital video as a media campaign on consumer buying interest as well as to determine how much influence the brand equity on consumer buying interest as active users of social media

Findings - After passing the calculations using regression and t-test, promotion through social media consisting of online communities and forums, blogs and social networks has a very strong influence on consumer buying interest compared to brand equity. This can be enhanced by strengthening social networking through social media to increase product sales, many companies still believe that social media as a low-cost promotional media but can increase sales, more promotion in social media will increase brand equity in the minds of consumers, so that in the end will benefit both sides.

Novelty - The research conducted in the context of Indonesia with original data on brand equity effect on confidence of consumers.
\end{abstract}

Type of Paper: Empirical

Keywords: Digital Video; Promotion; Brand Equity; Consumer Buying Interest; Social Media.

JEL Classification: M31, M37.

\section{Introduction}

Nowadays the majority of Indonesian people are very dependent on the smart phone, it can be said that most of the time spent using a smartphone equipped with an application that is very supportive of private life, such as social media, news, learning materials, sports activities, health, cooking recipes, application beauty, until the application for photography. Here is the data user penetration of internet services in Indonesia

\footnotetext{
* Paper Info: Received: February 2, 2017

Accepted: June 12, 2017

* Corresponding author:

E-mail: ayuningtyas.yuli@widyatama.ac.id

Affiliation: Universitas Widyatama, Indonesia.
} 


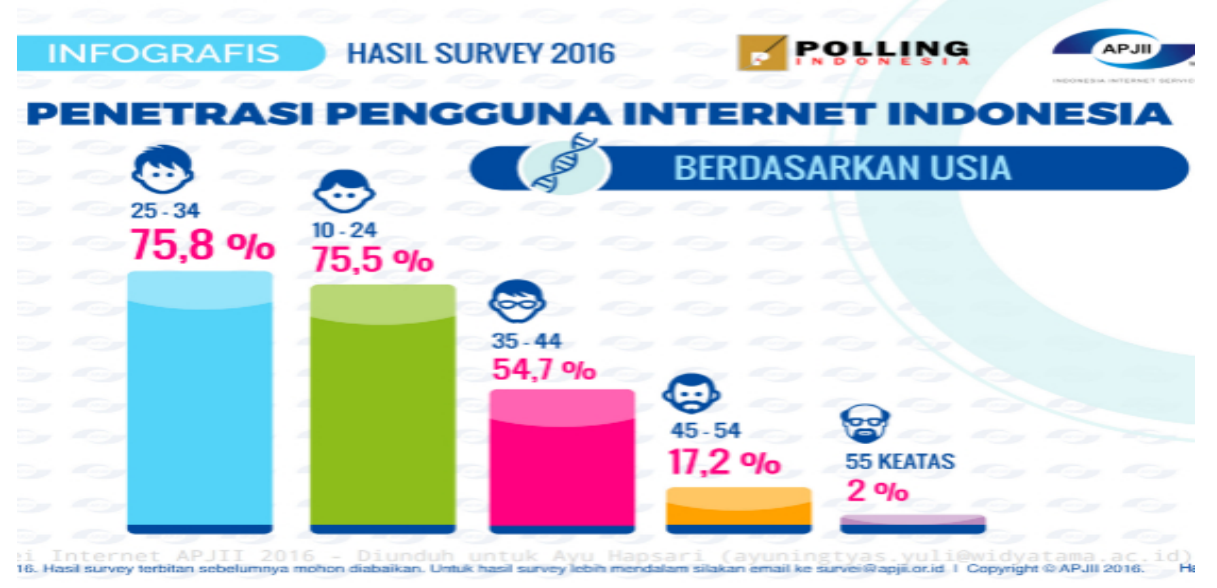

Figure 1. Internet user penetration in Indonesia Source: APJII, 2017

The figure above shows that active Internet users mostly in the age 25-34 years, who are in the productive age work, the Internet is used to support the activities of employment, greater mobility as well as maintain social networking, in this phase of the manufacture of digital video aimed at commercial and usually handled by professional, while those aged 10-24 years was ranked as the second largest, at this age the internet is required as a medium of self-actualization, the manufacture of digital video is limited to review a product, information about traveling, make-up tutorial or video about the biography of a person.

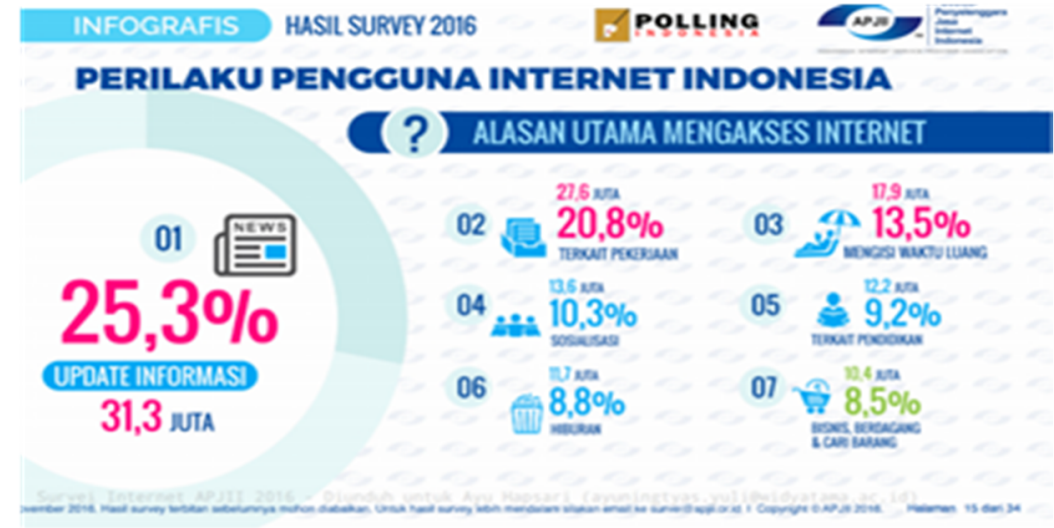

Figure 2. The Behavior of Internet Users in Indonesia Source: APJII, 2017

Image above further explained that turns users of Internet services do not have a high interest in the purchase of a product, it can be seen from the picture on the purchase of goods is only $8.5 \%$, social media only as a source of information of a product, the majority after seeing videos uploaded by some social media, they just need to update information about a product. Generally, a company needs to communicate with consumers to determine their needs and wants through the media, so it can affect change consumer thinking to make purchases of products and build the brand in the minds of consumers. In addition, the company can determine consumer response to their product directly and indirectly and also involving consumers in product promotion process, in addition, consumers can search for product information as much as possible through a media campaign. 


\subsection{Research Problem}

Based on the explanation above, we can know that the number of internet users in Indonesia is very much, but in this case the sales of some companies that use promotional services through social media does not increase in sales. This is after we conducted a pre-survey interview to 10 companies (which do not want to be mentioned brand), that their sales are still higher products sold in the store than through social media. Then seen from the brand equity, products sold through social media have good product quality, because the number of active users of social media that recommend to others. But in this study, products that already have good brand equity still cannot attract consumers to buy the product. Based on that problem, here are the research problem:

- How big Promotion Social Media has an influence to Consumer Buying Interest

- How big Brand Equity has an influence to Consumer Buying Interest

\section{Literature Review}

\subsection{Social Media}

Kotler and Armstrong (2008) says that: "Mix promotion (marketing communications mix) is a blend of specific advertising, sales promotion, public relations, personal selling, and a means of direct marketing is done by the company to communicate the value of customers in a persuasive and building customer relationships. According. Meanwhile, according to Kotler and Kevin (2012), social media is a means for consumers to share information, text, images, audio and video with each other and with company. There are three main platforms for social media:

Online communities and forums:

Online communities and forums that come in all shapes and sizes, many made by customers or groups of customers with no corporate affiliations, partly sponsored by a company whose members communicate with each other through social media about special interest related to the company's products.

Blogs:

Blogs can be used by persons and companies, blogs are used as a medium to convey to the public about the review of a product, or it could also be a review of a person.

Social network:

Social networking has become an important force in both business to consumer and business to business marketing. One of them Facebook, Twitter, Instagram, LinkedIn, etc. Different networks offer different benefits to the company.

\subsection{Brand Equity}

Brand equity is the added value given to products and services in the minds of consumers, feel and act in relation to brand, price, market share and profitability of a given brand for the company (Kotler and Keller, 2009: 263). The advantage of this scale is not only the small number of items but also the ability to measure the individual dimensions of brand equity. Thus, the measurement of brand equity will enable companies to evaluate their marketing programs. Also, if the brand equity is seen to suffer, further feedback can be obtained from consumers. This feedback will aid in: identifying product performance problems; identifying advertising/ positioning problems; and providing feedback to the firm's employees on where improvements need to be made (Lassar, Mittal, \& Sharma, 1995). While, the dimensions according to Aaker's Brand Equity in Ujang Sumarwan (2011) is composed of four dimensions, namely:

- Brand Awareness, the ability of consumers to recognize or remember a brand and associate it with a specific product category. 
- Perceived Quality, perceived quality of the brand that describes the overall customer response to the quality and benefits offered by the brand.

- Brand Association, the association of the brand with regard to everything that is associated in the memory of the customer to a brand.

- Brand Loyalty, a strong commitment to subscribe or purchase a brand consistently repeated in the future

\subsection{Consumer Buying Interest}

After determining the desired response from the audience, the communicator further develops an effective message. To learn more about the effects and communication that can be produced from a marketing communication perspective, the use of the hierarchical model approach gives an early conceptualization and response of the AIDA.

AIDA model proposed by Kotler (2002) is as follows:

- Attention (attract customers)

The emergence of consciousness and attention of consumers towards a marketing effort made by the producer.

- Interests (grow more interest in)

Their interest in the products offered by producers, even in the end arouse interest to have the product.

- Desire (desire to purchase the product)

After being interested then comes the desire to have the product.

- Action (purchases)

Actions taken by the consumer, after he passed the stage of interest in the product, then the desire to have the product up and then buy the product. But in this study the dimensions of action will not be used, because researchers focus on the activities of consumers before making a purchase.

\subsection{Research Paradigm}

Based on the above framework, the research paradigm can be made as follows:

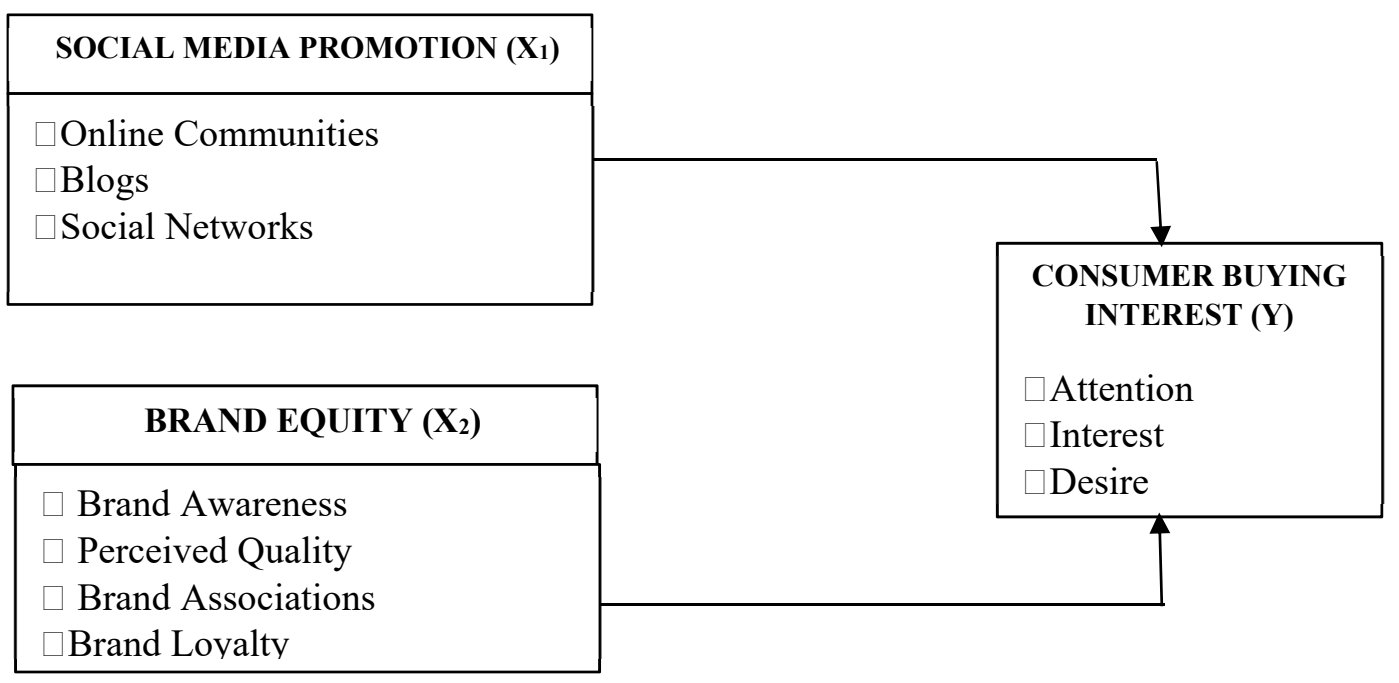

Figure 3. Research Paradigm 


\subsection{Hypothesis}

- Promotion Social Media has an influence to Consumer Buying Interest

- Brand Equity has an influence to Consumer Buying Interest

\section{Methodology}

\subsection{Method}

Verification method is used for this research, because they want to know how big the influence of social media promotion and brand equity on consumer buying interest. The sampling used is through iterative method so that it becomes 115 respondents. According Sitepu (1994) using iterative methods with analysis tools used in testing the hypothesis, that the path analysis which is basically calculated from the correlation coefficient between variables. Respondents were selected are active users of social media that have multiple accounts on different social media, because this research focuses on the promotion by social media.

To answer the problems in this study used multiple linear regression analysis (Multiple Regression) Analysis of regression is basically the study of the dependence of the dependent variable (bound) with one or more independent variables (explanatory variables / free), with the objective of estimating and / or estimated that the average population or values of the dependent variable based on the value of the independent variable is known (Ghozali, 2011). For the regression independent variables consist of two or more, the regression is also called regression. Therefore, the independent variables above have more than two variables, the regression in this study is called regression and data used normally interval or ratio scale. Regression equations in this research is to determine how much influence the independent variable is Social Media Promotion (X1) and Brand Equity (X2) on Consumer Buying Interest (Y).

Multiple regression equation of $\mathrm{X}$ to $\mathrm{Y}$ is as follows:

$$
Y=a+b 1 X 1+b 2 X 2+e
$$

\section{Description:}

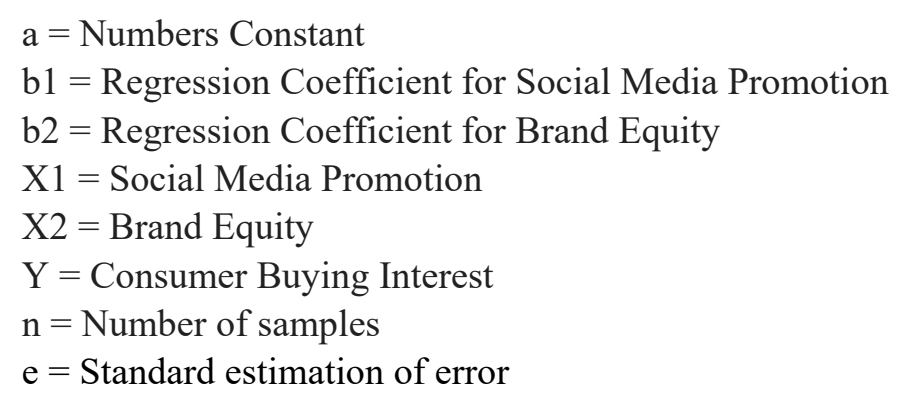

\subsection{Coefficient of Determination}

Meanwhile, to see how big the influence of independent variables on the dependent variable partially used the coefficient of determination (Kd) with the formula according to Narimawati (2010) as follows:

$$
K D=r^{2} \times 100 \%
$$

\section{Description:}

$\mathrm{KD}=$ coefficient of determination is sought

$\mathrm{r}^{2}=$ correlation coefficient 


\section{Results}

\subsection{Partial Test Calculation}

Table 1. Partial Test Calculation Result Correlations

\begin{tabular}{|l|l|r|r|r|}
\hline \multicolumn{2}{|c|}{} & \multicolumn{1}{c|}{ Y } & \multicolumn{1}{c|}{ X1 } & \multicolumn{1}{c|}{ X2 } \\
\hline \multirow{3}{*}{$\begin{array}{l}\text { Pearson } \\
\text { Correlation }\end{array}$} & $\mathrm{Y}$ & 1.000 & .734 & .714 \\
\cline { 2 - 5 } & $\mathrm{X} 1$ & .734 & 1.000 & .773 \\
\cline { 2 - 5 } & $\mathrm{X} 2$ & .714 & .773 & 1.000 \\
\hline \multirow{3}{*}{ Sig. (1-tailed) } & $\mathrm{Y}$ &. & .000 & .000 \\
\cline { 2 - 5 } & $\mathrm{X} 1$ & .000 &. & .000 \\
\cline { 2 - 5 } & $\mathrm{X} 2$ & .000 & .000 & \\
\hline \multirow{3}{*}{$\mathrm{N}$} & $\mathrm{Y}$ & 115 & 115 & 115 \\
\cline { 2 - 5 } & $\mathrm{X} 1$ & 115 & 115 & 115 \\
\cline { 2 - 5 } & $\mathrm{X} 2$ & 115 & 115 & 115 \\
\hline
\end{tabular}

\subsection{Hypothesis Testing Using t Count}

Table 2. Hypothesis Testing Using t count Coefficients ${ }^{\mathrm{a}}$

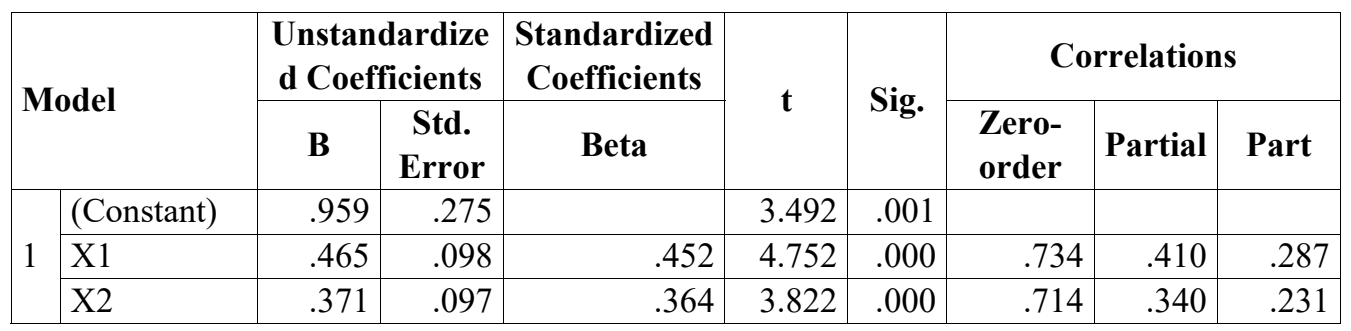

Dependent Variable: Y

From the results SPSS calculations, the coefficients used were beta coefficients or standardized coefficients (standardized Coefficient). Ho rejection criteria, if $t$ is greater than $t$ table or $t 0>t \alpha 1, n-5.0 .1658$.

\subsection{Equation}

Based on the results of data processing can be made in the structural equation. By including the estimated coefficient on the data processing structural equation is as follows:

$$
Y=0.959+0.452 X 1+0.364 X 2
$$

This means getting consumers to buy a very large influence on the promotion of social media, it is seen from the regression coefficient 0,452 while the brand equity of just giving the effect of 0.364 . So that consumers buying interest could increase if the variable enhanced social media campaign.

\section{Discussion}

\subsection{Partial Test Calculation}

There is influence between promotion of social media with consumer buying interest is calculated with a correlation coefficient of 0.734 . This indicates a very strong influence. a positive effect (no negatives in point 0.734) showed more effective an ad will make consumers buying interest is increasing. So the influence of promotion of social media to consumers buying interest is calculated by the formula $\mathrm{Kd}=\mathrm{r} 2 \times 100$, then $\mathrm{Kd}=$ (0.734) $2 \times 100=53.87 \%$ and the remaining $46.12 \%$ influenced by other variables not examined. The 
relationship between the variables of brand equity with consumers buying interest which is calculated by the correlation coefficient was 0.714 . This suggests a strong influence. This suggests a strong influence. a positive effect (no negative sign in number 0.714 ) indicates the greater brand equity will make consumers buying interest is increasing.

The influence of brand equity with consumers buying interest is calculated by the formula $\mathrm{Kd}=\mathrm{r} 2 \times 100$, then $\mathrm{Kd}=(0.714) 2 \times 100=50.97 \%$ and the remaining $49.02 \%$ influenced by other variables not examined. To test partially independent variables which have a significant effect on the dependent variable in the test with $\mathrm{t}$ test.

\subsection{Hypothesis t Count}

The first coefficient $=0452$, the value of $t$ count equal to 4,752 by taking a significance level $\alpha$ of $5 \%$, then the value of $t$ table or $t 0.05,113=0.1658$, so because $t$ is greater than $t$ table then reject Ho in other words promotion of social media influence on consumer purchase interest for 0734 . The second coefficient $=0.364$, the value of $t$ count equal to 3,822 by taking a significance level $\alpha$ of $5 \%$, then the value of $t$ table or t0.05, 113 $=0.1658$, so because $t$ is greater than $t$ table then reject Ho in other words brand equity influence on consumer purchase interest for 0714 .

\section{Conclusion}

After passing the calculations using regression and t-test, promotion through social media consisting of online communities and forums, blogs and social networks has a very strong influence on consumer buying interest compared to brand equity. This can be enhanced by strengthening social networking through social media to increase product sales, many companies still believe that social media as a low-cost promotional media but can increase sales, more promotion in social media will increase brand equity in the mind of consumers, so that in the end will benefit both sides. Brand equity will automatically increase the confidence of consumers, the more famous a brand then there is a sense of pride for the users of the brand.

\section{References}

Aaker, D. A. (1997). Manajemen ekuitas merek [Brand equity management]. Jakarta: Spektrum.

Ghozali, Imam. (2011). Aplikasi Analisis Multivariate Dengan Program IBM. SPSS 19 (5 $5^{\text {th }}$ Ed.) Semarang: Universitas Diponegoro.

Kotler, P., \& Armstrong, G. (2008). Principles of Marketing. Upper Saddle River, NJ: Pearson Prentice Hall

Kotler, P., \& Kevin, L. K. (2012). Marketing Management 13. Upper Saddle River, NJ: Pearson Prentice Hall

Kotler, P., \& Keller, K. L. (2009). Marketing Management. Upper Saddle River, NJ: Pearson Prentice Hall

Kotler, P. (2002) Marketing management. Upper Saddle River, NJ: Pearson Prentice Hall

Lukman, M. D. (2014). Analisis Pengaruh Ekuitas Merek Terhadap Keputusan Pembelian dan Kepuasan Konsumen Produk Teh Botol Sosro Kemasan Kotak [Analysis of the Effect of Brand Equity on Purchasing Decision and Consumer Satisfaction Product Bottle Tea Sosro Box Packaging]. Jurnal Administrasi Bisnis, 10(1). http://journal.unpar.ac.id/index.php/JurnalAdministrasiBisnis/article/.../1222.

Lassar, W., Mittal, B., \& Sharma, A. (1995). Measuring customer-based brand equity. Journal of consumer marketing, 12(4), 11-19. https://doi.org/10.1108/07363769510095270

Narimawati, U. (2010). Penulisan Karya Ilmiah. Bekasi. Penerbit : Ganesis.

Sitepu, N. S. (1994). Analisis Jalur (Path Analisis), Diterbitkan Atas Usaha Unit Pelayanan Statistika [Path Analysis (Path Analysis), Published on Service Business Unit Statistics], Jurusan FMIPA.

Sumarwan, U. (2003). Perilaku konsumen: Teori dan penerapannya dalam pemasaran. Ghalia Indonesia, Jakarta. www.apjii.or.id 